\title{
Combining Financial Information and Corporate Social Responsibility Related Information for Characterizing Corporate Disclosure: Some Insights From Moroccan Context
}

\author{
Youssef Saida ${ }^{1}$ \\ ${ }^{1}$ ESCA Ecole de Management, Casablanca, Morocco \\ Correspondence: Youssef Saida, ESCA Ecole de Management, Casablanca, 7, Rue Abou Youssef El Kindy, Bd. Mly \\ Youssef 20 070, Casablanca, Morocco.
}

Received: August 26, 2020

Accepted: October 16, 2020

Online Published: July 16, 2021

doi:10.5430/ijfr.v12n5p58

URL: https://doi.org/10.5430/ijfr.v12n5p58

\begin{abstract}
This paper deals with the corporate disclosure and therefore the option to predict the corporate disclosure through combining financial and non-financial information. In this paper, we study the corporate disclosure characteristics by investigating the predictability strength of specific financial performance indicators and corporate social responsiblity (CSR) related information. The sample of this research contains 58 organizations that had been awarded the label of the CSR in Morocco. A content analysis of corporate websites, financial statements and annual reports are used for each organization. Based on corporate disclosure content, two groups are constructed. We use four financial indicators for measuring the performance (financial information) and particular CSR related information (non-financial information) for these two groups. The discriminant analysis highlights to what extend specific information could predict the nature corporate disclosure content. As results, these indicators and information show different levels of ability to predict corporate disclosure content. Our findings, when confronted to the literature, explicit convergences about the predictability of corporate disclosure content.
\end{abstract}

Keywords: corporate disclosure, financial communication, corporate social responsibility disclosure, stakeholders, discriminant analysis

\section{Introduction}

The corporate disclosure is recognized as an important task for modern organization. In fact, organization has to reveal information regarding corporate policies and practices (financial performance, CSR, etc.). This revelation should be well-designed to fit particular stakeholders' expectations. Appropriating these expectations is fundamental for organization to enhance its image and reputation, and thus gaining competitive advantages.

The content of corporate disclosure should be well-designed to fit business and corporate strategies. In fact, corporate disclosure is a set of practices conducted by organization management to achieve particular objectives. These objectives are related to sharing financial information and disclosing about CSR activities. As a result of attempting to accomplish these objectives, organization meets diverse stakeholders' expectations. In this sense, organization shares financial information to support primarily investors' decision making process and CSR-related information to serve organizational image and reputation. In others words, this organizational behavior seeks to shape its disclosure content by combining financial and non-financial information (CSR-related information) to meet specific regulation and for being recognized as responsible and socially responsible.

Theoretically, the nature of corporate disclosure content draws attention to organizational behavior regarding stakeholders' expectations. In fact, disclosing financial information provides visibility and transparency regarding particular aspects of organization businesses and activities such as: assets, performance, risks, etc. In addition, organization looks for revealing non-financial information (i.e. CSR-related information) with the purpose of seeking legitimacy and improving organizational image. However, combining financial and non-financial information in order to build an effective corporate disclosure seems to be not deliberately studied. In others words, previous researches put emphasis separately on how organization communicates its financial data and the manner by which it is disclosing information relating to CSR activities. The aim of this paper is to study the nature of corporate disclosure and then analyze to what extent this disclosure could be discriminated throughout combining financial and 
non-financial information.

For this research, the theoretical background is based on the existing literature relating to the content of corporate disclosure. First, the literature emphasizing how corporate finance information is treated and communicated. Second, the CSR disclosure literature is also used to highlight organizational behavior to deal with stakeholders in order to enhance corporate image and reputation. Third, corporate disclosure literature used to explain the way how organization could combine all kind of information for interacting with competitive stakeholders in order to serve a specific agenda.

\section{Literature Review}

Communicating information is one of the most important tasks that organization management should lead appropriately. Indeed, disclosing information related to organization practices and businesses could be seen as a tool to deal with different kind of environment stakeholders (investors, suppliers, customers, employees, NGO, etc.). Subsequently, organization has to conduct a communication of different kind of information (financial and non-financial information) to meet a set of requirements from competitive environment. These requirements are apprehended as responsibilities that leverage organizational behavior regarding strategies and businesses. In other words, this organizational behavior highlights the management mindset that influences the way how organization is disclosing and interacting with the all environment stakeholders. Given to this corporate policy regarding the disclosure of different kind of information, the aim is to provide capabilities to deal with environment complexity, and thus becoming more flexible to integrate deliberately more stakeholders' expectations at corporate level. This integration is performed throughout what is called "corporate disclosure" that implies particular practices and processes.

\subsection{Financial Information Communication}

Reporting financial information is about communicating financial data displaying financial performance, business risks, market transactions, etc. Actually, we use financial statements and annual reports as tools for disclosing this kind of information. Primarily, financial information disclosure is shaped to provide more transparency for particular stakeholders like investors (Fischer \& Stocken, 2010; Hauswald \& Marquez, 2003; Johnston et al., 2007a; LEE et al., 2011; LOUGHRAN \& MCDONALD, 2014; Malenko, 2014; Stocken \& Verrecchia, 2004). This objective is fundamental for supporting stakeholders (investors) decision-making process. That support depends on the financial information quality which is recognized a tool for reducing the problem of information asymmetry of the stakeholders (Andina-Díaz, 2012; Awaya \& Krishna, 2016; Choi \& Lee, 2014; Fischer \& Stocken, 2001; Klumpp, 2007; Rahman, 2014; Sicherman et al., 2016).

Financial information communication process should be well-matched to serve corporate agenda and as a consequence reports appropriate financial information related to economic/financial performance, market performance, etc. This category of information is helpful for many stakeholders (investors, public authorities, analysts, etc.) and therefore should be insightful in order to support effectively stakeholders' decision-making process (Bergman \& Roychowdhury, 2008a; Bushman et al., 2004a; Gentry \& Shen, 2010; Haggard et al., 2008; HERMALIN \& WEISBACH, 2012; MELITSKI \& MANOHARAN, 2014; Venkatachalam, 2000a). So, organization management has to implement an appropriate system to make financial information reliable and available. By saying that, this system seeks to collect, classify and generate financial information to support effective decision-making (Awaya \& Krishna, 2016; Choi \& Lee, 2014; Hauswald \& Marquez, 2003; Serigne Mansour Tall, 2004; Stocken \& Verrecchia, 2004).

\subsection{CSR Disclosure}

CSR-related information reporting could be seen as a communication of non-financial information related to specific activities conducted by organization management. Indeed, corporate policy reveals information on the subject of particular activities accomplished by organization for being socially responsible in its competitive environment. That revealing of CSR related information is called "CSR disclosure" (Basu \& Palazzo, 2008; Haji, 2013; Kolk \& Pinkse, 2010; Maignan \& Ralston, 2002; Reverte, 2009). In fact, this kind of disclosure is about reporting social and environmental issues to take into consideration particular stakeholders' expectations that have been judged important to deal with. In this sense, organization management is reporting information which is not usually disclosed throughout financial information communication system. Additionally, it is communicated information related to environmental impact, donations, and effects of climate change and employee issues (D. Dhaliwal et al., 2014; Schwartz \& Carroll, 2003; Uddin et al., 2018). Consequently, CSR-related information disclosure could be seen as a tool to assess CSR activities and then as a way to display how organization is interacting with specific stakeholders 
in larger competitive environment - at micro and macro levels. In the same context, disclosing CSR-related information is by which corporate governance enhances organization image and reputation (Bushman et al., 2004b; Carroll, 1991; Cohen et al., 2011; Lange \& Washburn, 2012).

Furthermore, throughout revealing CSR disclosure, organization is attempting to be accountable to a wider audience than shareholders targeted by financial information communication. By doing so, organization management integrates particular stakeholders' satisfaction as an important variable to take into consideration at corporate level. This satisfaction is crucial for organization because these stakeholders can influence somehow its businesses, practices and strategies (De Tienne \& Lewis, 2005; Dan S. Dhaliwal et al., 2012; Holder-Webb et al., 2009). In other words, CSR-related information disclosure attempts to make a shift in organization mindset by leveraging the way how the stakeholders' relationship is managed. This new mindset is about transforming stakeholders' satisfaction to a source of sustainable strategic advantages (D.S. Dhaliwal et al., 2012; Dias et al., 2016; M. P. Johnson, 2015; Ortas et al., 2014; Waddock et al., 2002).

\subsection{Corporate Disclosure}

Corporate disclosure is recognized as an integrated approach for communicating financial and non-financial information. Traditionally, corporate policies communicate predominantly financial information to fit particular stakeholders' expectations such as: investors, public authorities, shareholders, etc. Alternatively stated, corporate disclosure prioritizes financial information than other information. This kind of communication was well-matched with a competitive environment with particular trend in terms of stakeholders' expectations. In modern business landscape, corporate disclosure has to communicate different kind of information in order to fit various stakeholders' expectations. This stakeholders' expectation is important to conduct by organization management for dealing with a relationship toward complex environment (Bergman \& Roychowdhury, 2008b; Bushman et al., 2004a; Haggard et al., 2008; Khurana et al., 2006; Tjio, 2009; Venkatachalam, 2000a). This complexity is about managing various stakeholders' expectations which are becoming a component to integrate in corporate governance. This integration is operated by corporate disclosure aggregating financial and non-financial information (Bhojraj \& Sengupta, 2003a; Hahn \& Lülfs, 2014; HERMALIN \& WEISBACH, 2012; Reid \& Toffel, 2009; Stocken, 2000, 2000), throughout publishing integrated reports (Hou \& Reber, 2011; Koseoglu et al., 2021; Lu \& Wang, 2020; Salvi et al., 2020; Siueia et al., 2019)

At organizational level, combining financial and non-financial information (CSR-related information) is generally made to interact properly with a complex and uncertain environment. This interaction is about how corporate governance seeks to manage the relationship between organization and different kind of stakeholders. That management could impact positively organization performance (Bergman \& Roychowdhury, 2008a; Bushee \& Noe, 2000a; Jiao, 2011a; Lenter et al., 2003; Venkatachalam, 2000b), cost of capital (Botosan \& Plumlee, 2002; Urquiza et al., 2012) and the quality of the disclosure practices (Bens \& Monahan, 2004; Bhojraj \& Sengupta, 2003b; Bushee \& Noe, 2000b; Bushman et al., 2004b; Chan et al., 2014; Francis et al., 2008; Jiao, 2011b). Theoretically, corporate disclosure is usually studies throughout the association between corporate communication and financial information communication or the impact of using information related to CSR activities on corporate governance. In other words, there is a lack in previous researches about how organization combines financial and non-financial information to make its corporate disclosure (Bamber et al., 2010; Dan S. Dhaliwal et al., 2012; Hidalgo et al., 2011; LU, 2014; Oh \& Shin, 2020; Zdolsek \& Kolar, 2013).

In this paper, we aim to study the option to predict corporate disclosure content throughthout financial indicators and CSR-related information. Therefore, we try to study whether financial indicators and particular CSR-related information could predict the nature of corporate disclosure content. We use PER - Price Earning Ratio, PBR Price Book Ratio, ROE - Return on Equity and OP - Operating Profit as the most financial indicators used to measure organization market performance and value. As well, we choose particular CSR-related information as the better sign to bring to light organizational behavior regarding CSR-related activities (Bushee \& Noe, 2000a; Castka \& Balzarova, 2008; Hutchins \& Sutherland, 2008; Jamali, 2008; Jizi et al., 2013). The choice of financial indicators as predictors is justified by the fact that they are frequently theoretically associated with financial information communication (Gentry \& Shen, 2010; D. E. Johnson et al., 2009; Johnston et al., 2007b; MELITSKI \& MANOHARAN, 2014; Melkers \& Willoughby, 2005). Hence, we investigate how independent variables - the financial indicators and CSR-related information discriminate among the members of groups constructed based on corporate disclosure content.

Five hypotheses were set up:

$\mathrm{H}_{1}$ : CSR Communication is a good predictor of corporate disclosure nature. 
$\mathrm{H}_{2}$ : OP is a good predictor of corporate disclosure nature.

$\mathrm{H}_{3}$ : PER is a good predictor of corporate disclosure nature.

$\mathrm{H}_{4}$ : PBR is a good predictor of corporate disclosure nature.

$\mathrm{H}_{5}: \mathrm{ROE}$ is a good predictor of corporate disclosure nature.

\section{Method}

For testing the hypotheses cited above, quantitative research approach is used in this study, because it is well-matched to the subject of our research.

\subsection{Participant (Subject) Characteristics}

In this research, we aim to investigate about the option for predicting corporate disclosure nature throughout a combination of particular financial indicators and CSR related information. Our investigation is conducted with companies quoted in Moroccan stock exchange. This choice is justified by the fact that these companies published regularly their financial statements and reports in their websites. As well, the most of these companies had the label of CSR or practice somehow CSR related activities and actions.

\subsection{Sampling Procedures}

To fit the purpose of this research, convenience sampling method was applied for getting data (financial statements, annual reports, CSR reports, etc.) from companies' websites. In this inquiry, 64 companies listed in Moroccan stock exchange were involved.

\subsection{Measures and Covariates}

For this paper, the data-collection process was based on data found in regular companies' communication. We use a content analysis of websites for each company in order to outline the corporate disclosure nature. Accordingly, two groups of companies are constructed. Based on the financial and non-financial information, we use four financial performance indicators and specific CSR related information for these two groups. The reasons of this choice were effectiveness in data gathering process to fit the requirements of discriminant analysis.

Two categories of variables were used in this investigation. First, corporate disclosure nature is a qualitative variable. It contains two categories such as: basic and content-oriented stakeholders. It was measured through companies' websites' content analysis driven by multiple-choice survey questions with exhaustive and mutually exclusive items. As a result of that, we attempt to bring to light the nature of the corporate disclosure. Second, four quantitative variables such as: PER - Price Earning Ratio, PBR - Price Book Ratio, ROE - Return on Equity and OP Operating Profit representing financial performance indicators gathered from Moroccan stock exchange database. Third, CSR communication is a qualitative variable which is containing two categories such as: Ad hoc and Formalized. It was measured through companies CSR reports' content analysis driven by multiple-choice survey questions with exhaustive and mutually exclusive items.

\section{Results}

This section illustrates the results of discriminant analysis conducted throughout SPSS software. The data used in this analysis are from Moroccan stock exchange data file. SPSS output is displayed in tables.

We aim to investigate about the relationship between one categorical variable and the combination of four continuous variables and one categorical variable. In particular, the purpose is to identify the dimensions needed to express this relationship. Therefore, we are interested to predict a classification based on the combination of continuous variables and categorical variable in order to evaluate to what extend these variables (continuous and categorical) differentiate the categories constructed. Additionally, we are interested to investigate the degree to which these variables can be used to discriminate between the groups.

Table 1 recapitulates the analysis dataset in terms of valid and excluded observations. In our study, all of the observations in the dataset are valid. 
Table 1. Analysis case processing summary

\begin{tabular}{llll}
\hline Unweighted Cases & $\mathrm{N}$ & Percent \\
\hline Valid & & 64 & 90,1 \\
\hline \multirow{2}{*}{ Excluded } & Missing or out-of-range group codes & 0 &, 0 \\
\cline { 2 - 4 } & At least one missing discriminating variable & 7 & 9,9 \\
\cline { 2 - 4 } & $\begin{array}{l}\text { Both missing or out-of-range group codes and at least one } \\
\text { missing discriminating variable }\end{array}$ & 0 &, 0 \\
\cline { 2 - 4 } & Total & 7 & 9,9 \\
\hline Total & & 71 & 100,0 \\
\hline
\end{tabular}

The second table displays the distribution of observations into two groups within corporate disclosure nature. As a consequence, we can notice the frequency of observations into each of the two groups. In this case, we can see that the PBR and CSR Communication means values are approximately the same between the two groups. However, we haven't the same situation regarding the OP values. Besides, we observe that the weighted number of observations in each group is equal to the unweighted number of observations in each group.

Table 2. Group statistics

\begin{tabular}{llllll}
\hline Disclosure & \multicolumn{2}{l}{ Mean } & Std. Deviation & \multicolumn{2}{l}{ Valid N (listwise) } \\
\cline { 3 - 6 } & & & & Unweighted & Weighted \\
\hline Basic & CSR_Com & 1,175000 &, 3848076 & 40 & 40,000 \\
\cline { 2 - 6 } & OP & 267844888,323000 & 461917746,4432926 & 40 & 40,000 \\
\cline { 2 - 6 } & PER & 26,875000 & 67,1699672 & 40 & 40,000 \\
\cline { 2 - 6 } & PBR & 2,325000 & 2,1529646 & 40 & 40,000 \\
\cline { 2 - 6 } & ROE & 15,525000 & 14,8979219 & 40 & 40,000 \\
\hline Content-oriented & CSR_Com & 1,750000 &, 4423259 & 24 & 24,000 \\
\cline { 2 - 6 } & OP & 1635701362,220000 & 2702325648,2298536 & 24 & 24,000 \\
\cline { 2 - 6 } & PER & 21,208333 & 17,4380373 & 24 & 24,000 \\
\cline { 2 - 6 } & PBR & 2,541667 & 1,8876985 & 24 & 24,000 \\
\cline { 2 - 6 } & ROE & 14,708333 & 12,3516560 & 64 & 64,000 \\
\cline { 2 - 6 } Total & CSR_Com & 1,390625 &, 4917474 & 64,000 \\
\cline { 2 - 6 } & OP & 780791066,034375 & 1800995280,7517753 & 64 & 64,000 \\
\cline { 2 - 6 } & PER & 24,750000 & 53,9600087 & 64 & 64,000 \\
\cline { 2 - 6 } & PBR & 2,406250 & 13,0448833 & 64 & 64000 \\
\cline { 2 - 6 } & ROE & 15,218750 & & &
\end{tabular}

In the Table 3, the first column indicates the canonical linear discriminant function. In this analysis, corporate disclosure nature has two levels and five discriminating variables were used, so one function is calculated. This function is a projection of the data onto a dimension that best differentiates between the groups. In the second column, we have the eigenvalue of the matrix product of the inverse of the within-group sums-of-squares and cross-product matrix and the between-groups sums-of-squares and cross-product matrix. In our analysis, the eigenvalue is 0.548 . The importance of this eigenvalue stresses the function's discriminating abilities. As well, the \% of variance indicates that the function calculated accounts for $100 \%$ of the discriminating ability of the discriminating variables. The final column is about the canonical correlation of the predictor variables (CSR Communication, PER, PBR, OP and ROE) and the two groups in corporate disclosure nature (basic and content-oriented stakeholders). From this analysis, the canonical correlation value is 0.595 . 
Table 3. Eigenvalues

\begin{tabular}{lllll}
\hline Function & Eigenvalue & $\%$ of Variance & Cumulative \% & Canonical Correlation \\
\hline 1 &, $548^{\mathrm{a}}$ & 100,0 & 100,0 &, 595 \\
\hline
\end{tabular}

${ }^{a}$ First 1 canonical discriminant functions were used in the analysis.

The Wilks' Lambda value displayed by the Table 4 is 0.646 . Besides, the Chi-square (25.990) testing that the canonical correlation of the function calculated is equal to zero. As a result, we have the null hypothesis is that the function has no discriminating ability. This hypothesis is tested using this Chi-square statistic. The $p$-value associated with the Chi-square value is 0.000 (smaller than 0.05 ). Therefore, the null hypothesis is rejected. It indicates that there is a significant difference between the two groups based on the predictor variables.

Table 4. Wilk's lambda

\begin{tabular}{lllll}
\hline Test of Function(s) & Wilks' Lambda & Chi-square & df & Sig. \\
\hline 1 &, 646 & 25,990 & 5 &, 000 \\
\hline
\end{tabular}

The Table 5 shows the coefficients that can be used to estimate the discriminant score.

Table 5. Standardized canonical discriminant function coefficients

\begin{tabular}{ll}
\hline & Function \\
\cline { 2 - 2 } & 1 \\
\hline CSR_Com &, 868 \\
\hline OP &, 348 \\
\hline PER &,- 046 \\
\hline PBR &,- 089 \\
\hline ROE &,- 018 \\
\hline
\end{tabular}

The magnitudes of these coefficients indicate how strongly the discriminating variables affect the score. In our analysis, we observe that the coefficient for CSR Communication (0.868) in the function is greater in magnitude than the coefficients for the other two variables (PER, PBR and ROE smaller than 0.30). However, the coefficient for OP $(0.348)$ is greater than 0.30 which is a sign of moderate predictability. In consequence, CSR Communication will have the greatest impact ( $H_{1}$ is accepted) of the three $\left(H_{3}, H_{4}\right.$ and $H_{5}$ are rejected) on the discriminant score. As well, OP will have a moderate impact ( $H_{2}$ is accepted) (appendix A).

The Table 6 indicates the canonical structure of the discriminant function. It represents the correlations between the five discriminating variables (CSR Communication, OP, PER, PBR and ROE) and the dimensions created with the discriminant function. In the analysis, this correlation is strong in the case of CSR Communication (0.939) and moderate for OP $(0.539)$.

Table 6. Structure matrix

\begin{tabular}{ll}
\hline & Function \\
\cline { 2 - 2 } & 1 \\
\hline CSR_Com &, 939 \\
\hline OP &, 539 \\
\hline PBR &, 070 \\
\hline PER &,- 069 \\
\hline ROE &,- 039 \\
\hline
\end{tabular}


In the Table 7, we find the means of the discriminant function scores by group for the function calculated above. Therefore, we can see that the basic group has a mean of -0.564 , the content-oriented stakeholders group has a mean of 0.940 .

Table 7. Functions at group centroids

\begin{tabular}{ll}
\hline Disclosure & Function \\
\cline { 2 - 2 } & 1 \\
\hline Basic &,- 564 \\
\hline Content-oriented &, 940 \\
\hline
\end{tabular}

Table 8 is similar to the Analysis Case Processing Summary displayed by Table 1. However, in this table we find "Processed" cases that were successfully classified based on the discriminant analysis. Also, we are listed the reasons why an observation may not have been processed. In the analysis, we can see that all of the observations in the dataset were successfully classified.

Table 8. Classification processing summary

\begin{tabular}{lll}
\hline Processed & & 71 \\
\hline Excluded & Missing or out-of-range group codes & 0 \\
\cline { 2 - 3 } & At least one missing discriminating variable & 0 \\
\hline Used in Output & 71 \\
\hline
\end{tabular}

The Table 9 shows the distribution of observations into the virtual financial communication content groups used as a starting point in the analysis. The default prior distribution is an equal allocation into the two groups. The discriminant function has classified 40 as basis and 24 as content-oriented stakeholders. So, this function calculated is able to classify all of the observations (appendix B).

Table 9. Prior probabilities for groups

\begin{tabular}{llll}
\hline Disclosure & Prior & \multicolumn{2}{l}{ Cases Used in Analysis } \\
\cline { 3 - 4 } & & Unweighted & Weighted \\
\hline Basic &, 500 & 40 & 40,000 \\
\hline Content-oriented &, 500 & 24 & 24,000 \\
\hline Total & 1,000 & 64 & 64,000 \\
\hline
\end{tabular}

\section{Discussion}

The aim of this paper is to highlight, throughout discriminant analysis, the possibility for discriminating among the two groups constructed based on corporate disclosure content. In such a case, four financial indicators and CSR Communication are applied as predictor variables. Our findings involve the enlightenment of some insights raised by observing the results derived from the analysis. First, CSR Communication and OP - Operating Profit are underlined as indicators that has the strong discriminating ability between the two groups constructed. In view of that, the content of corporate disclosure is first and foremost leveraged by CSR Communication and then the OP. In other words, these indicators could be seen as predictors the nature of corporate disclosure content whether is basic or content-oriented. Consequently, the tendency of these two indicators - CSR Communication and OP bring to light to what extend the content of the corporate disclosure is content-oriented. Second, the other financial indicators for instance PER - Price Earning Ratio, PBR - Price Book Ratio and ROE - Return on Equity are highlighted as indicators without considerable discriminating capability among the two groups constructed. As a result, these indicators could not be apprehended as predictors regarding the trend of corporate disclosure content. Subsequently, 
explaining to what extend the corporate disclosure content is content-oriented could not be achieved throughout these three financial indicators. These three indicators give emphasis to the organization effectiveness regarding its businesses performance and market value. The CSR Communication is the strong predictor of the corporate disclosure content. This CSR-related information communication is becoming an important component in corporate disclosure. Disclosing this kind of information is about communicating information related to motivations behind conducting CSR activities; Characteristics of CSR activities; organizational practices regarding environmental and social issues; stakeholders targeted throughout this kind of disclosure; etc. Hence, disclosing non-financial information like CSR-related information seems to be insightful to characterize the content of corporate disclosure. In other words, it is possible throughout CSR-related information communication to emphasize whether the content of corporate disclosure is basic or oriented to fit specific stakeholders' expectations. Besides, the OP - Operating Profit is also an indicator with a moderate ability to predict the content of corporate disclosure. This indicator is one of the financial indicators used usually by many stakeholders (shareholders, institutional investors, etc.) because it puts emphasis on the organization's financial effectiveness more than others financial indicators. This stakeholders' choice is explained by the fact that indicator is related to organization core business. Other financial indicators used in the analysis above are for the most part related to financial performance and organization market value, and in consequence less insightful regarding the organization core business. In other words, these financial indicators seem to be more oriented to serve stakeholders' perception on the subject of organization assets assessment, market risk and future earnings. However, these indicators seem to be less insightful about the explanation of the corporate disclosure content.

In this perspective, we find some convergence between our findings and the literature. In fact, throughout our analysis displayed above, specific information (financial and non financial) give sufficient explanation on the subject of the nature of corporate disclosure content. This combination of information is about integrating financial information with CSR-related information to characterize corporate disclosure. So, specific financial information financial performance indicators and CSR-related information have the ability to predict whether the corporate disclosure is basic or more oriented to fit stakeholders' expectations in complex environment. Deliberately, organization is making its corporate disclosure by using formalized practices and processes to communicate specific financial information in despite of the organization market performance and value (Bergman \& Roychowdhury, 2008c; Connelly et al., 2011; Esqueda, 2016; Gentry \& Shen, 2010; Jiao, 2011a; Johnston et al., 2007b; Singhvi \& Desai, 1971). In the same case, organization communicates also CSR-related information to strengthen its financial communication and thus accomplishing a specific strategy in financial markets and dealing with stakeholders in macro-environment (Babiak et al., 2010; Bansal \& DesJardine, 2014; Bushee \& Noe, 2000c; Fischer \& Stocken, 2010; Hutchins \& Sutherland, 2008; Jamali, 2008; Jiao, 2011c; Lang \& Lundholm, 1996). In essence, corporate disclosure reveals what is important about financial information and CSR-related information for different kind of stakeholders. This combination of financial and non-financial information gives emphasis to organizational choice about the content of that disclosure. This content is leveraged by a certain way to serve a corporate agenda for the purpose of balancing between financial performance and social performance. This organizational behavior underlines to what extent corporate disclosure is made to reveal adequate information about corporate finance and sustainable activities. This disclosure more oriented to satisfy stakeholders' expectations and thus enhancing corporate image and reputation (Bushman et al., 2004b; Durden, 2008; Frias-Aceituno et al., 2013; García-Marzá, 2005; Holder-Webb et al., 2009; Preuss et al., 2009; Sen et al., 2006).

Finally, it could be approved the fact that is important for organization to combine financial and non-financial information for making an appropriate corporate disclosure. This combination is based on corporate strategy which is the prerequisite to decide the optimal combination of financial and non-financial information in order to serve corporate agenda. This agenda highlights to what extent specific stakeholders' expectations is important and thus how organization behaves to achieve accurately the satisfaction of these stakeholders. So, this research provides important insights by highliting the fact that specific information - financial and non-financial are disposed to predict the nature of corporate disclosure. This predicitiblity could be used to explain annual reports content, used as a tool for making corporate disclosure. Moreover, this information combinaison is important to underline, for the reason that it is supposed to be managed deliberately at corporate level to fit strategic intention in competitive environment.

\section{Conclusion}

This article had as purpose to enhance our knowledge regarding the nature of the corporate disclosure content and the ability of specific financial and non-financial information (CSR-related information) for predict the nature of the corporate disclosure. In this respect, we attempt to give emphasis to whether the corporate disclosure content could be characterized throughout combining financial information and CSR-related information. Therefore, this prediction 
is fundamental to lay emphasis on the idea that combination of information is leveraged to make the corporate disclosure more oriented to fit stakeholders' expectations.

This research has some limitations by which further research questions could be opened. These limits can be summarized in two points. First, results highlighted above are related to Moroccan context. Thus, future researches could be conducted in other contexts with the intention of getting deeper our findings and making an appropriate comparison. Second, in this paper we use CSR Communication as an item to emphasize non-financial information, although others items are also available, and in consequence could be used to investigate about the strength of their predictability regarding the corporate disclosure content.

\section{References}

Andina-Díaz, A. (2012). Screening and signaling in communication. The Scandinavian Journal of Economics, 114(2), 480-499.

Awaya, Y., \& Krishna, V. (2016). On communication and collusion. The American Economic Review, 106(2), 285-315.

Babiak, P., Neumann, C. S., \& Hare, R. D. (2010). Corporate psychopathy: Talking the walk. Behavioral Sciences and the Law, 28(2), 174-193. https://doi.org/10.1002/bsl.925

Bamber, L. S., John, J., \& Wang, I. Y. (2010). What's my style? The influence of top managers on voluntary corporate financial disclosure. The Accounting Review, 85(4), 1131-1162.

Bansal, P., \& DesJardine, M. (2014). Business sustainability: It is about time. Strategic Organization, 12(1), 70-78. https://doi.org/10.1177/1476127013520265

Basu, K., \& Palazzo, G. (2008). Corporate social responsibility: A process model of sensemaking. Academy of Management Review, 33(1), 122-136. https://doi.org/10.5465/AMR.2008.27745504

Bens, D. A., \& Monahan, S. J. (2004). Disclosure quality and the excess value of diversification. Journal of Accounting Research, 42(4), 691-730.

Bergman, N. K., \& Roychowdhury, S. (2008). Investor sentiment and corporate disclosure. Journal of Accounting Research, 46(5), 1057-1083.

Bhojraj, S., \& Sengupta, P. (2003). Effect of corporate governance on bond ratings and yields: The role of institutional investors and outside directors. The Journal of Business, 76(3), 455-475. https://doi.org/10.1086/344114

Botosan, C. A., \& Plumlee, M. A. (2002). A re-examination of disclosure level and the expected cost of equity capital. Journal of Accounting Research, 40(1), 21-40.

Bushee, B. J., \& Noe, C. F. (2000). Corporate disclosure practices, institutional investors, and stock return volatility. Journal of Accounting Research, 38, 171-202. https://doi.org/10.2307/2672914

Bushman, R. M., Piotroski, J. D., \& Smith, A. J. (2004). What determines corporate transparency?. Journal of Accounting Research, 42(2), 207-252.

Carroll, A. B. (1991). The pyramid of corporate social responsibility: Toward the moral management of organizational stakeholders. Business Horizons, 34(4), 39-48. https://doi.org/10.1016/0007-6813(91)90005-G

Castka, P., \& Balzarova, M. A. (2008). Adoption of social responsibility through the expansion of existing management systems. Industrial Management and Data Systems, 108(3), 297-309. https://doi.org/10.1108/02635570810858732

Chan, M. C., Watson, J., \& Woodliff, D. (2014). Corporate governance quality and CSR disclosures. Journal of Business Ethics, 125(1), 59-73.

Choi, S., \& Lee, J. (2014). Communication, coordination, and networks. Journal of the European Economic Association, 12(1), 223-247.

Cohen, J., Holder-Webb, L., Nath, L., \& Wood, D. (2011). Retail investors' perceptions of the decision-usefulness of economic performance, governance, and corporate social responsibility disclosures. Behavioral Research in Accounting, 23(1), 109-129. https://doi.org/10.2308/bria.2011.23.1.109

Connelly, B. L., Certo, S., Ireland, R., \& Reutzel, C. R. (2011). Signaling theory: A review and assessment. Journal of Management, 37, 39-67. 
De Tienne, K. B., \& Lewis, L. W. (2005). The pragmatic and ethical barriers to corporate social responsibility disclosure: The Nike case. Journal of Business Ethics, 60(4), 359-376. https://doi.org/10.1007/s10551-005-0869-x

Dhaliwal, D. S., Radhakrishnan, S., Tsang, A., \& Yang, Y. G. (2012). Nonfinancial disclosure and analyst forecast accuracy: International evidence on corporate social responsibility disclosure. Accounting Review, 87(3), 723-759. https://doi.org/10.2308/accr-10218

Dhaliwal, D., Li, O. Z., Tsang, A., \& Yang, Y. G. (2014). Corporate social responsibility disclosure and the cost of equity capital: The roles of stakeholder orientation and financial transparency. Journal of Accounting and Public Policy, 33(4), 328-355. https://doi.org/10.1016/j.jaccpubpol.2014.04.006

Dias, A., Rodrigues, L. L., \& Craig, R. (2016). Global financial crisis and corporate social responsibility disclosure. Social Responsibility Journal, 12(4), 654-671. https://doi.org/10.1108/SRJ-01-2016-0004

Durden, C. (2008). Towards a socially responsible management control system. Accounting, Auditing and Accountability Journal, 21(5), 671-694. https://doi.org/10.1108/09513570810872969

Esqueda, O. A. (2016). Signaling, corporate governance, and the equilibrium dividend policy. The Quarterly Review of Economics and Finance, 59, 186-199. https://doi.org/10.1016/j.qref.2015.06.005

Fischer, P. E., \& Stocken, P. C. (2001). Imperfect information and credible communication. Journal of Accounting Research, 39(1), 119-134.

Fischer, P. E., \& Stocken, P. C. (2010). Analyst information acquisition and communication. The Accounting Review, 85(6), 1985-2009.

Francis, J., Nanda, D., \& Olsson, P. (2008). Voluntary disclosure, earnings quality, and cost of capital. Journal of Accounting Research, 46(1), 53-99.

Frias-Aceituno, J. V., Rodriguez-Ariza, L., \& Garcia-Sanchez, I. M. (2013). The role of the board in the dissemination of integrated corporate social reporting. Corporate Social Responsibility and Environmental Management, 20(4), 219-233. https://doi.org/10.1002/csr.1294

García-Marzá, D. (2005). Trust and dialogue: Theoretical approaches to ethics auditing. Journal of Business Ethics, 57(3), 209-219. https://doi.org/10.1007/s10551-004-8202-7

Gentry, R. J., \& Shen, W. (2010). The relationship between accounting and market measures of firm financial performance : how strong is it?. Journal of Managerial Issues, 22(4), 514-530.

Haggard, K. S., Martin, X., \& Pereira, R. (2008). Does voluntary disclosure improve stock price informativeness?. Financial Management, 37(4), 747-768.

Hahn, R., \& Lülfs, R. (2014). Legitimizing negative aspects in gri-oriented sustainability reporting: a qualitative analysis of corporate disclosure strategies. Journal of Business Ethics, 123(3), 401-420.

Haji, A. A. (2013). Corporate social responsibility disclosures over time: Evidence from Malaysia. Managerial Auditing Journal, 28(7), 647-676. https://doi.org/10.1108/MAJ-07-2012-0729

Hauswald, R., \& Marquez, R. (2003). Information technology and financial services competition. The Review of Financial Studies, 16(3), 921-948.

Hermalin, B. E., \& Weisbach, M. S. (2012). Information disclosure and corporate governance. The Journal of Finance, 67(1), 195-233.

Hidalgo, R. L., García-Meca, E., \& Martínez, I. (2011). Corporate governance and intellectual capital disclosure. Journal of Business Ethics, 100(3), 483-495.

Holder-Webb, L., Cohen, J. R., Nath, L., \& Wood, D. (2009). The supply of corporate social responsibility disclosures among U.S. firms. Journal of Business Ethics, 84(4), 497-527. https://doi.org/10.1007/s10551-008-9721-4

Hou, J., \& Reber, B. H. (2011). Dimensions of disclosures : Corporate social responsibility (CSR) reporting by media companies. Public Relations Review, 37(2), 166-168. https://doi.org/10.1016/j.pubrev.2011.01.005

Hutchins, M. J., \& Sutherland, J. W. (2008). An exploration of measures of social sustainability and their application to supply chain decisions. Journal of Cleaner Production, 16(15), 1688-1698. https://doi.org/10.1016/j.jclepro.2008.06.001 
Jamali, D. (2008). A stakeholder approach to corporate social responsibility: A fresh perspective into theory and practice. Journal of Business Ethics, 82(1), 213-231. https://doi.org/10.1007/s10551-007-9572-4

Jiao, Y. (2011a). Corporate disclosure, market valuation, and firm performance. Financial Management, 40(3), 647-676.

Jizi, M. I., Salama, A., Dixon, R., \& Stratling, R. (2013). Corporate governance and corporate social responsibility disclosure: evidence from the us banking sector. Journal of Business Ethics, 125(4), 601-615. https://doi.org/10.1007/s10551-013-1929-2

Johnson, D. E., Davis, S. B., \& Albright, T. L. (2009). Examining the relationship between employee attitudes and a firm's financial performance: a theoretical framework and causal investigation. Journal of Managerial Issues, 21(3), 367-382.

Johnson, M. P. (2015). Sustainability management and small and medium-sized enterprises: managers' awareness and implementation of innovative tools. Corporate Social Responsibility and Environmental Management, 22(5), 271-285. https://doi.org/10.1002/csr.1343

Johnston, M. K., Reed, K., Lawrence, K., \& Onken, M. (2007a). The link between communication and financial performance in simulated organizational teams. Journal of Managerial Issues, 19(4), 536-553.

Khurana, I. K., Pereira, R., \& Martin, X. (2006). Firm growth and disclosure : an empirical analysis. The Journal of Financial and Quantitative Analysis, 41(2), 357-380.

Klumpp, T. (2007). Communication in financial markets with several informed traders. Economic Theory, 33(3), 437-456.

Kolk, A., \& Pinkse, J. (2010). The integration of corporate governance in corporate social responsibility disclosures. Corporate Social Responsibility and Environmental Management, 17(1), 15-26. https://doi.org/10.1002/csr.196

Koseoglu, M. A., Uyar, A., Kilic, M., Kuzey, C., \& Karaman, A. S. (2021). Exploring the connections among CSR performance, reporting, and external assurance: Evidence from the hospitality and tourism industry. International Journal of Hospitality Management, 94, 102819. https://doi.org/10.1016/j.ijhm.2020.102819

Lang, M. H., \& Lundholm, R. J. (1996). Corporate disclosure policy and analyst behavior. The Accounting Review, 71(4), 467-492.

Lange, D., \& Washburn, N. T. (2012). Understanding attributions of corporate social irresponsibility. Academy of Management Review, 37(2), 300-326. https://doi.org/10.5465/amr.2010.0522

Lee, T. D., Haley, E., Yun, T. W., \& Chung, W. (2011). US retirement financial services advertising's financial information provisions, communication strategies and judgmental heuristic cues. The Journal of Consumer Affairs, 45(3), 391-418.

Lenter, D., Slemrod, J., \& Shackelford, D. (2003). Public disclosure of corporate tax return information: accounting, economics, and legal perspectives. National Tax Journal, 56(4), 803-830.

Loughran, T., \& Mcdonald, B. (2014). Measuring readability in financial disclosures. The Journal of Finance, 69(4), 1643-1671.

LU, H.-Y. (2014). Does disclosure of non-financial statement information reduce firms' propensity to under-invest?. Quarterly Journal of Finance and Accounting, 51(3-4), 1-44.

Lu, J., \& Wang, J. (2020). Corporate governance, law, culture, environmental performance and CSR disclosure: A global perspective. Journal of International Financial Markets, Institutions and Money, 101264. https://doi.org/10.1016/j.intfin.2020.101264

Maignan, I., \& Ralston, D. A. (2002). Corporate social responsibility in Europe and the U.S.: Insights from businesses' self-presentations. Journal of International Business Studies, 33(3), 497-514. https://doi.org/10.1057/palgrave.jibs.8491028

Malenko, N. (2014). Communication and decision-making in corporate boards. The Review of Financial Studies, 27(5), 1486-1532.

Melitski, J., \& Manoharan, A. (2014). Performance measurement, accountability, and transparency of budgets and financial reports. Public Administration Quarterly, 38(1), 38-70.

Melkers, J., \& Willoughby, K. (2005). Models of performance-measurement use in local governments: understanding 
budgeting, communication, and lasting effects. Public Administration Review, 65(2), 180-190.

Oh, F. D., \& Shin, D. (2020). Religion and corporate disclosure quality. Hitotsubashi Journal of Economics, 61(1), 20-37. https://doi.org/10.2307/26918273

Ortas, E., Moneva, J. M., \& Álvarez, I. (2014). Sustainable supply chain and company performance: A global examination. Supply Chain Management, 19(3), 332-350. https://doi.org/10.1108/SCM-12-2013-0444

Preuss, L., Haunschild, A., \& Matten, D. (2009). The rise of CSR: Implications for HRM and employee representation. International Journal of Human Resource Management, 20(4), 953-973. https://doi.org/10.1080/09585190902770893

Rahman, D. (2014). The power of communication. The American Economic Review, 104(11), 3737-3751.

Reid, E. M., \& Toffel, M. W. (2009). Responding to public and private politics: corporate disclosure of climate change strategies. Strategic Management Journal, 30(11), 1157-1178.

Reverte, C. (2009). Determinants of corporate social responsibility disclosure ratings by Spanish listed firms. Journal of Business Ethics, 88(2), 351-366. https://doi.org/10.1007/s10551-008-9968-9

Salvi, A., Vitolla, F., Giakoumelou, A., Raimo, N., \& Rubino, M. (2020). Intellectual capital disclosure in integrated reports: The effect on firm value. Technological Forecasting and Social Change, 160, 120228. https://doi.org/10.1016/j.techfore.2020.120228

Schwartz, M. S., \& Carroll, A. B. (2003). Corporate social responsibility: A three-domain approach. Business Ethics Quarterly, 13(4), 503-530.

Sen, S., Bhattacharya, C. B., \& Korschun, D. (2006). The role of corporate social responsibility in strengthening multiple stakeholder relationships: A field experiment. Journal of the Academy of Marketing Science, 34(2), 158-166. https://doi.org/10.1177/0092070305284978

Serigne M. T. (2004). Senegalese émigrés: new information \& communication technologies. Review of African Political Economy, 31(99), 31-48.

Sicherman, N., Loewenstein, G., Seppi, D. J., \& Utkus, S. P. (2016). Financial attention. The Review of Financial Studies, 29(4), 863-897.

Singhvi, S. S., \& Desai, H. B. (1971). An empirical analysis of the quality of corporate financial disclosure. The Accounting Review, 46(1), 129-138.

Siueia, T. T., Wang, J., \& Deladem, T. G. (2019). Corporate social responsibility and financial performance: a comparative study in the sub-Saharan Africa banking sector. Journal of Cleaner Production, 226, 658-668. https://doi.org/10.1016/j.jclepro.2019.04.027

Stocken, P. C. (2000). Credibility of voluntary disclosure. The RAND Journal of Economics, 31(2), 359-374. https://doi.org/10.2307/2601045

Stocken, P. C., \& Verrecchia, R. E. (2004). Financial reporting system choice and disclosure management. The Accounting Review, 79(4), 1181-1203.

Tjio, H. (2009). Enforcing corporate disclosure. Singapore Journal of Legal Studies, 332-364.

Uddin, S., Siddiqui, J., \& Islam, M. A. (2018). Corporate social responsibility disclosures, traditionalism and politics: a story from a traditional setting. Journal of Business Ethics, 151(2), 409-428. https://doi.org/10.1007/s10551-016-3214-7

Urquiza, F. B., Navarro, M. C. A., \& Trombetta, M. (2012). Disclosure strategies and cost of capital. Managerial and Decision Economics, 33(7/8), 501-509.

Venkatachalam, M. (2000a). Discussion of corporate disclosure practices, institutional investors, and stock return volatility. Journal of Accounting Research, 38, 203-207. https://doi.org/10.2307/2672915

Waddock, S. A., Bodwell, C., \& Graves, S. B. (2002). Responsibility: The new business imperative. Academy of Management Executive, 16(2), 132-148. https://doi.org/10.5465/AME.2002.7173581

Zdolsek, D., \& Kolar, I. (2013). Management disclosure practices for disaggregated (financial) information in Slovenian unlisted companies. Journal of East European Management Studies, 18(2), 264-289. 


\section{Appendix}

Appendix A: Tests of Equality of Group Means

\begin{tabular}{llllll}
\hline & Wilks' Lambda & F & df1 & df2 & Sig. \\
\hline CSR_Com &, 674 & 29,925 & 1 & 62 &, 000 \\
\hline OP &, 863 & 9,871 & 1 & 62 &, 003 \\
\hline PER &, 997 &, 163 & 1 & 62 &, 688 \\
\hline PBR &, 997 &, 166 & 1 & 62 &, 685 \\
\hline ROE &, 999 &, 051 & 1 & 62 &, 822 \\
\hline
\end{tabular}

\section{Appendix B: Separate-Groups Graphs}
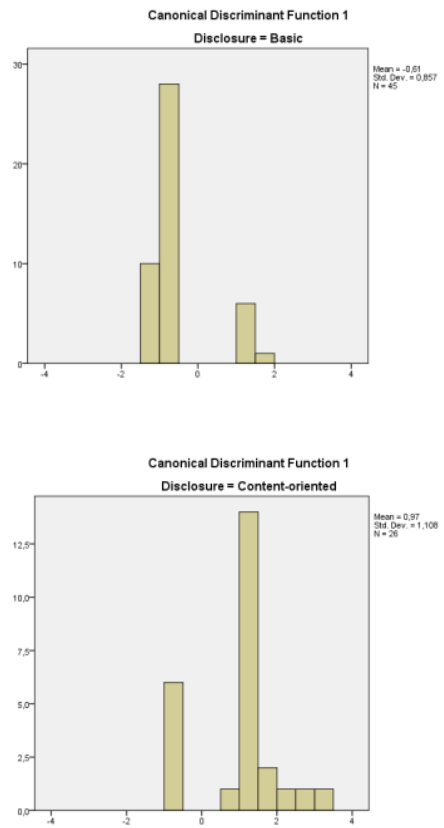

\section{Copyrights}

Copyright for this article is retained by the author(s), with first publication rights granted to the journal.

This is an open-access article distributed under the terms and conditions of the Creative Commons Attribution license (http://creativecommons.org/licenses/by/4.0/). 